\title{
INDIRECT TENSILE TEST AS A SIMPLE METHOD FOR RUT RESISTANCE EVALUATION OF ASPHALT CONCRETE
}

\section{P. ZIELIŃSKI ${ }^{1}$}

\begin{abstract}
The paper presents the dependence of ITS results at the elevated temperature $\left(40^{\circ} \mathrm{C}\right)$ on rutting parameters, i.e. proportional rut depth $\left(\mathrm{PRD}_{\mathrm{AIR}}\right)$ and wheel tracking speed $\left(\mathrm{WTS}_{\mathrm{AIR}}\right)$, obtained at the temperature of $60^{\circ} \mathrm{C}$. The asphalt mixture samples were prepared in the gyratory compactor, but ITS tests were conducted with typical Marshall press, at a loading rate of $50 \mathrm{~mm} / \mathrm{min}$. Correlation analyses show a strong relationships between ITS results and rutting parameters, whereby the correlation coefficients obtained are higher for the PRD $\mathrm{AIR}_{\text {parameter }}$ $(\mathrm{r}=-0.88)$ than $\mathrm{WTS}_{\mathrm{AIR}}(\mathrm{r}=-0.81)$. Using the obtained regression functions, the prediction limits as well as confidence limits were calculated, which allowed to develop criteria for assessing resistance to rutting on the basis of ITS test, and taking into account the technical requirements in Poland.
\end{abstract}

Keywords: asphalt concrete (AC), indirect tensile strength (ITS), proportional rut depth (PRD), wheel tracking speed (WTS), permanent deformation of the asphalt pavement

\section{INTRODUCTION}

The resistance of the asphalt mixture to permanent deformations is one of the basic features that must be ensured at the design stage of mixture composition. The permanent deformation resistance of asphalt mixes is usually evaluated on the characteristics of binder and mix, tested in the laboratory, in accelerated test equipment or in real pavement sections. To verify the resistance to permanent deformation of asphalt mixtures in laboratory various methods are currently used, which

\footnotetext{
${ }^{1}$ PhD., Eng., Cracow University of Technology, Faculty of Civil Engineering, ul. Warszawska 24, 
include different wheel tracking tests (WTT), flow number (FN), flow time (FT), asphalt pavement analyzer (APA), repeated load permanent deformation (RLPD), dynamic modulus (DM), etc. AlKhatebb et al. [1] found that the FN test results showed better fitting to the expected trend than the dynamic creep test results. On the other hand Zhang et al. [10] conducted a comparative evaluation of the FN, DM and RLPD tests, found that the FN Index, in contrast to the classical FN (cycles) parameter, exhibited a better correlation with results of both the DM and RLPD tests. Xu et al. [8] carried out the partial triaxial test (PTT), and stated that a strong correlation was found between the strain slope value at the second stage in the PTT and the total rut depth in the WTT. In the work of Radhakrishnan et al. [7], a strong correlation was observed between the time lag in the resilient modulus test and the rut depth measured in the wheel tracking test. In European countries, the most common study of HMA resistance to the permanent deformation is the rutting test. For the preparation of samples and the execution of the rutting test, a large amount of mixture as well as special technical equipment is needed, which also affects the cost of the test. Therefore, this research was carried out to indicate a simple test that will allow faster, easier and cheaper assessment of the potential resistance of asphalt mixtures to the permanent deformation. According to the results of work conducted by Christensen et al. [2], such testing may be the indirect tensile strength (ITS) on cylindrical samples, with appropriate adjustment of the test temperature and the speed of piston travel. The exemplary recommended conditions of the ITS test according to the work [2] is the temperature $20^{\circ} \mathrm{C}$ lower than the critical pavement temperature due to permanent deformation at the piston's speed in the press equal to $3.75 \mathrm{~mm} / \mathrm{min}$. In the following years, Christensen and Bonaquist [3] modified the testing conditions so that one could use the popular Marshall press with a piston speed of $50 \mathrm{~mm} / \mathrm{min}$, proposing a correction by increasing the test temperature by $10^{\circ} \mathrm{C}\left(10^{\circ} \mathrm{C}\right.$ below the critical asphalt pavement temperature). A very high coefficient of determination was obtained, describing the relationship between the test conditions given above $\left(\mathrm{R}^{2}=0.99\right)$. Then, basing on the results of the study, the authors [3] developed criteria for the requirements for the indirect tensile strength of the asphalt mixture samples depending on the design traffic load and the vehicle speed. Research on the correlation between asphalt mixes indirect tensile strength and the rut resistance was also carried out by Zaniewski and Srinivasan [9] as well as Khousla and Harikrishnan [5]. In both of the above reports it was found that there is a strong relationship between the indirect tensile strength of asphalt mixes samples and their resistance to permanent deformation. The reverse results were obtained by Kruger and Horak [6], statistical analysis revealed poor correlation between the ITS, measured with Marshall press at a temperature of $25^{\circ} \mathrm{C}$, and the rut results $\left(\mathrm{R}^{2}=0.17\right)$. Isailovic, Wistuba and Augusto [4] measured permanent deformation by triaxial test at a temperature of $50^{\circ} \mathrm{C}$ and indirect tensile fatigue 
test at $20^{\circ} \mathrm{C}$. The poor relationship obtained in the above works $[4,6]$ can be explained by the use of a relatively low ITS test temperature.

In this work an attempt was made to develop a relationship between the indirect tensile strength under the elevated temperature conditions, tested on samples compacted in the gyratory press, and HMA parameters of resistance to rutting, tested in accordance with the technical requirements in Poland [12], i.e. in a small wheel tracker. Additionally, on the basis of the obtained functional dependences, considering the confidence limit and the limit of estimation prediction, propositions of ITS requirements at $40^{\circ} \mathrm{C}$ were given as a criterion for HMA's resistance to permanent deformations in relation to technical requirements [12].

\section{MATERIALS AND METHODS}

The scope of the tests comprised 21 asphalt concrete mixes, intended for base, binder and wearing courses, with nominal grain size: $0 / 22 \mathrm{~mm}, 0 / 16 \mathrm{~mm}$ and $0 / 8 \mathrm{~mm}$. A various binder, i.e. paving bitumen (35/50 or 50/70), polymer modified (25/55-60 or 45/80-55) or rubber modified were used in this mixtures. Besides, in same mixtures, the addition of reclaimed asphalt pavement (RAP) or reclaimed asphalt shingles (RAS) was used. A detailed specification of the composition and physical properties of the tested asphalt concrete mixes are given in Table 1.

Table 1. Composition and physical characteristics of AC samples compacted in a gyratory press

\begin{tabular}{|c|c|c|c|c|c|c|c|}
\hline O.N. & AC Mark & $\begin{array}{c}\text { Bitumen Content } \\
{[\%]}\end{array}$ & $\begin{array}{c}\text { Density } \\
{\left[\mathrm{g} / \mathrm{cm}^{3}\right]}\end{array}$ & $\begin{array}{c}\text { Bulk Density } \\
{\left[\mathrm{g} / \mathrm{cm}^{3}\right]}\end{array}$ & $\begin{array}{c}\text { Air Voids } \\
{[\%]}\end{array}$ & $\begin{array}{c}\text { VMA } \\
{[\%]}\end{array}$ & $\begin{array}{c}\text { VFB } \\
{[\%]}\end{array}$ \\
\hline 1 & AC 16 W 35/50 & 4.4 & 2.620 & 2.602 & 0.7 & 12.1 & 94.3 \\
\hline 2 & AC 16 W PMB 25/55-60 & 4.4 & 2.621 & 2.601 & 0.8 & 12.2 & 93.7 \\
\hline 3 & AC 16 W PMB 25/55-60 & 4.5 & 2.537 & 2.504 & 1.3 & 12.6 & 89.7 \\
\hline 4 & AC 16 W PMB +RAP & 4.5 & 2.561 & 2.529 & 1.2 & 12.6 & 90.1 \\
\hline 5 & AC 16 W PAT+RAP & 4.5 & 2.553 & 2.514 & 1.5 & 12.8 & 88.1 \\
\hline 6 & AC 16 W PAT+RAP+JUV & 4.5 & 2.539 & 2.529 & 0.4 & 11.8 & 96.7 \\
\hline 7 & AC 16 W 35/50 & 4.4 & 2.618 & 2.607 & 0.4 & 11.9 & 96.5 \\
\hline 8 & AC 16 W 35/50 & 4.4 & 2.618 & 2.603 & 0.6 & 12.0 & 95.2 \\
\hline 9 & AC 22 P 35/50 & 4.0 & 2.626 & 2.529 & 3.7 & 13.8 & 73.3 \\
\hline 10 & AC 22 P 35/50 & 3.9 & 2.605 & 2.529 & 2.9 & 12.8 & 77.2 \\
\hline 11 & AC 22 P 35/50 & 4.0 & 2.519 & 2.49 & 1.2 & 11.1 & 89.6 \\
\hline 12 & AC 16 W PMB 25/55-60 & 4.4 & 2.613 & 2.605 & 0.3 & 11.8 & 97.4 \\
\hline 13 & AC 22 P 35/50 & 3.8 & 2.626 & 2.529 & 3.7 & 13.3 & 72.2 \\
\hline 14 & AC 16 W 35/50 & 4.5 & 2.557 & 2.502 & 2.2 & 13.4 & 84.0 \\
\hline 15 & AC 16 W 35/50 & 4.5 & 2.561 & 2.525 & 1.4 & 12.8 & 89.0 \\
\hline 16 & AC 16 W 50/70 & 4.5 & 2.564 & 2.535 & 1.1 & 12.5 & 91.0 \\
\hline 17 & AC 16 W 50/70+1\%RAS & 4.4 & 2.619 & 2.564 & 2.1 & 13.4 & 84.3 \\
\hline 18 & AC 16 W 50/70+1\%RAS & 4.4 & 2.626 & 2.601 & 1.0 & 12.4 & 92.3 \\
\hline 19 & AC 16 W 35/50 & 4.4 & 2.595 & 2.564 & 1.2 & 12.5 & 90.4 \\
\hline 20 & AC 8 S PMB 45/80-55 & 5.7 & 2.601 & 2.584 & 0.7 & 15.4 & 95.8 \\
\hline 21 & AC 16 W 35/50+1\%RAS & 4.4 & 2.626 & 2.614 & 0.5 & 12.0 & 96.2 \\
\hline
\end{tabular}


For all of the tested asphalt mixtures, test samples were prepared as follows:

- Samples with a diameter of $100 \mathrm{~mm}$ and a height of $100 \mathrm{~mm}( \pm 2.5 \mathrm{~mm})$, compacted with constant energy in a gyratory press according to PN-EN 12697-31 [16] up to 200 rotations, which were then cut in half for test specimens with an approximate height of $50 \mathrm{~mm}$.

- $\quad$ Plate samples with dimensions $305 \mathrm{~mm} \times 305 \mathrm{~mm}$ and height 40-60 $\mathrm{mm}$ (depending on the grain size of the mix), compacted with roller compactor according to PN-EN 12697-33 [17] to 99\% $( \pm 1 \%$ ) bulk density determined according to the Marshall method [15].

All plate samples were used to study rutting in a small apparatus according to PN-EN 12697-22 [13], method B in air, at $60^{\circ} \mathrm{C}, 2$ plates were prepared for each mix. As a result of the test, the proportional rut depth expressed in percentage $\left(\mathrm{PRD}_{\mathrm{AIR}}\right)$ and the speed of rut increase in the second test phase expressed in $\mathrm{mm} / 1000$ load cycles (WTS $\mathrm{AIR}$ ) were determined.

Cylindrical samples were used for testing indirect tensile strength (ITS) according to PN-EN 1260723 [14], using the Marshall press at a piston speed of $50 \mathrm{~mm} / \mathrm{min}$, at the temperature of $40^{\circ} \mathrm{C}$. The accepted ITS test parameters are consistent with those given in [3]. For each mixture, 2-6 samples were tested (coefficient of variation of ITS results below $10 \%$ were obtained), the force was recorded as a function of piston displacement until the sample was destroyed and the indirect tensile strength was calculated according to Eq. (2.1).

$$
\operatorname{ITS}=\frac{2 * P}{\pi * D * L} * 10^{6}
$$

where:

ITS - indirect tensile strength in $\mathrm{kPa}$, rounded up to three significant digits, $\mathrm{P}$ - peak load value in $\mathrm{kN}$, rounded up to three significant digits, D - sample diameter in $\mathrm{mm}$, rounded to the decimal, L - sample length in $\mathrm{mm}$, rounded to the decimal.

\section{RESULTS AND DISCUSSION}

The average values of rutting test parameters at $60^{\circ} \mathrm{C}$ and indirect tensile strength at $40^{\circ} \mathrm{C}$ are given in Table 2. Statistical analyses of the results were started by determining the Spearman linear correlation between the rutting parameters (PRD and WTS), the ITS results and AC sample composition parameters such as: bitumen content (B), air voids content in asphalt mixture (VIM), voids in mineral aggregate (VMA) and voids filled with bitumen (VFB). Among the above-mentioned parameters, significant correlation coefficients showed only the ITS results at $40^{\circ} \mathrm{C}$, this relation is 
negative and the coefficients are, respectively: -0.82 for the WTS parameter and -0.88 for the PRD parameter. Properties related to the composition of AC showed no linear relationship with rutting parameters, i.e. the absolute values of correlation coefficients ranged from 0.04 to 0.30 . Detailed results of correlation analyses, including correlation coefficients and probability values, testing the statistical significance of estimated correlations, are given in Table 3.

Table 2. Results of rutting and ITS for AC samples

\begin{tabular}{|c|c|c|c|c|}
\hline O.N. & AC Mark & $\begin{array}{c}\text { PRD } \\
{[\%]}\end{array}$ & $\begin{array}{c}\text { WTS } \\
{[\mathrm{mm} / 1000 \text { cycles }]}\end{array}$ & $\begin{array}{c}\text { ITS }\left(40^{\circ} \mathrm{C}\right) \\
{[\mathrm{kPa}]}\end{array}$ \\
\hline 1 & AC 16 W 35/50 & 4.9 & 0.070 & 448 \\
\hline 2 & AC 16 W PMB 25/55-60 & 3.4 & 0.030 & 722 \\
\hline 3 & AC 16W PMB 25/55-60 & 3.3 & 0.040 & 819 \\
\hline 4 & AC 16 W PMB +RAP & 3.0 & 0.038 & 849 \\
\hline 5 & AC 16 W PAT+RAP & 2.4 & 0.030 & 763 \\
\hline 6 & AC 16 W PAT+RAP+JUV & 3.3 & 0.039 & 669 \\
\hline 7 & AC 16 W 35/50 & 7.4 & 0.173 & 455 \\
\hline 8 & AC 16 W 35/50 & 6.3 & 0.135 & 451 \\
\hline 9 & AC 22 P 35/50 & 7.9 & 0.173 & 456 \\
\hline 10 & AC 22 P 35/50 & 8.0 & 0.182 & 432 \\
\hline 11 & AC 22 P 35/50 & 4.5 & 0.052 & 579 \\
\hline 12 & AC 16 W PMB 25/55-60 & 3.3 & 0.048 & 716 \\
\hline 13 & AC 22 P 35/50 & 6.3 & 0.152 & 533 \\
\hline 14 & AC 16 W 35/50 & 5.8 & 0.107 & 564 \\
\hline 15 & AC 16 W 35/50 & 3.5 & 0.050 & 761 \\
\hline 16 & AC 16 W 50/70 & 5.0 & 0.099 & 643 \\
\hline 17 & AC 16 W 50/70+1\%RAS & 9.2 & 0.217 & 378 \\
\hline 18 & AC 16 W 50/70+1\%RAS & 8.5 & 0.233 & 464 \\
\hline 19 & AC 16 W 35/50 & 2.7 & 0.041 & 908 \\
\hline 20 & AC 8 S PMB 45/80-55 & 5.8 & 0.084 & 649 \\
\hline 21 & AC 16 W 35/50+1\%RAS & 5.3 & 0.094 & 519 \\
\hline
\end{tabular}

Table 3. Results of correlation coefficients and their statistical significance tests (P-value)

\begin{tabular}{|c|c|c|c|c|c|c|}
\hline AC parameters & VIM & VFB & VMA & ITS & PRD & WTS \\
\hline B & -0.534 & 0.576 & 0.493 & 0.296 & 0.203 & 0.276 \\
& $(0.013)$ & $(0.006)$ & $(0.023)$ & $(0.192)$ & $(0.378)$ & $(0.226)$ \\
\hline VIM & - & -0.997 & 0.459 & -0.269 & 0.421 & 0.435 \\
& & $(0.000)$ & $(0.037)$ & $(0.238)$ & $(0.057)$ & $(0.049)$ \\
\hline VFB & & - & 0.407 & 0.253 & -0.398 & -0.418 \\
& & & $(0.067)$ & $(0.269)$ & $(0.074)$ & $(0.059)$ \\
\hline VMA & & & - & -0.043 & 0.300 & 0.243 \\
& & & & $(0.855)$ & $(0.185)$ & $(0.290)$ \\
\hline ITS & & & & - & -0.883 & -0.818 \\
& & & & & $(0.000)$ & $(0.000)$ \\
\hline PRD & & & & & - & 0.971 \\
& & & & & & $(0.000)$ \\
\hline
\end{tabular}

Using regression function in Statgraphics program [11] relations between the indirect tensile strength at $40^{\circ} \mathrm{C}$ and $60^{\circ} \mathrm{C}$ rutting parameters (PRD and WTS) were determined. The multiplicative model has shown the best fit for both the PRD and the WTS parameters, which is compatible with Christensen and Bonaquist [3], a detailed comparison of model matching is given in Table 4. 
Table 4. Comparison of alternative regression models

\begin{tabular}{|c|c|c|c|c|c|}
\hline \multirow[t]{2}{*}{ O.N. } & \multirow[t]{2}{*}{ Model } & \multicolumn{2}{|c|}{ For PRD parameter } & \multicolumn{2}{|c|}{ For WTS parameter } \\
\hline & & Correlation & R-squared [\%] & Correlation & R-squared [\%] \\
\hline 1 & Multiplicative & -0.910 & 82.7 & -0.866 & 75.1 \\
\hline 2 & Exponential & -0.906 & 82.0 & -0.855 & 73.1 \\
\hline 3 & Recipropal-X & 0.905 & 81.8 & 0.853 & 72.8 \\
\hline 4 & S-curve & 0.902 & 81.3 & 0.865 & 74.8 \\
\hline 5 & Recipropal-Y & 0.899 & 80.9 & 0.833 & 69.4 \\
\hline 6 & Logarithmic-X & -0.899 & 80.8 & -0.841 & 70.7 \\
\hline 7 & Square root-Y & -0.898 & 80.8 & -0.843 & 71.1 \\
\hline 8 & Square root-X & -0.892 & 79.6 & -0.831 & 69.0 \\
\hline 9 & Linear & -0.883 & 77.9 & -0.818 & 66.8 \\
\hline 10 & Double reciprocal & -0.872 & 76.1 & -0.823 & 67.7 \\
\hline 11 & Logistic & \multicolumn{2}{|c|}{ No fit } & -0.853 & 72.8 \\
\hline 12 & Log probit & \multicolumn{2}{|c|}{ No fit } & -0.865 & 74.8 \\
\hline
\end{tabular}

In the case of the tested mixtures, a high determination coefficient was observed between ITS at $40^{\circ} \mathrm{C}$ with rutting parameters, with a better fit for the PRD $\left(\mathrm{R}^{2}=82 \%\right)$ than for the WTS parameter $\left(\mathrm{R}^{2}=\right.$ $75 \%$ ). The obtained function dependence, representing a PRD value is presented in Eq. (3.1) but regression model and ANOVA table for multiplicative regression are shown in Table 5 and in Table 6 respectively. This relationship is statistically significant and it explains $82 \%$ of the variability of the results. Moreover, from Table 6 it can be seen that P-value of the regression model is very much less than 0.05 , indicating that at $95 \%$ confidence level it can be concluded that there exists a strong relation between the indirect tensile strength value and the proportional rut depth in $\mathrm{AC}$ mixtures.

$$
P R D_{A I R}=48220 * I T S^{-1.443}
$$

Correlation coefficient $-\mathrm{R}=-0.9095$

R-squared $=82.71 \%$

R-squared (adjusted for d.f.) $=81.8 \%$

Standard Error of Estimation - SSE $=0.175$

Mean Absolute Error - MAE $=0.132$

Durbin-Watson Statistics $=1.53>1,4-$ autocorrelation of non-existing residuals

Table 5. Parameter estimates of multiplicative regression model (PRD)

\begin{tabular}{|c|c|c|c|c|}
\hline Parameter & Estimate & Standard Error & T-stat & P-value \\
\hline Intercept* & 10.7835 & 0.9665 & 11.1579 & 0.0000 \\
\hline Slope & -1.4433 & 0.15138 & -9.5344 & 0.0000 \\
\hline
\end{tabular}

* Intercept $=\ln (\mathrm{a})$ 
Table 6. Analysis of variance table for PRD regression model

\begin{tabular}{|c|c|c|c|c|c|}
\hline Source & DF (Degree of Freedom) & SS (Sum of Squares) & MS (Mean Square) & F-stat & P-value \\
\hline Model & 1 & 2.7734 & 2.7734 & 90.90 & 0.0000 \\
\hline Residual & 19 & 0.5797 & 0.0305 & & \\
\hline Total & 20 & 3.3531 & & & \\
\hline
\end{tabular}

The formula for the WTS parameter is described by Eq. (3.2), regression model and ANOVA table for multiplicative regression are shown in Table 7 and in Table 8 respectively. Obtained relationship is statistically significant and it explains $74 \%$ of the variability of the results. Moreover, from Table 8 it can be seen that P-value of the regression model is very much less than 0.05 (a level critical value), indicating that at $95 \%$ confidence level it can be concluded that there exists a strong relation between the indirect tensile strength value and the wheel tracking speed in AC mixtures.

$$
W T S_{A I R}=198925 * I T S^{-2.309}
$$

Correlation coefficient $-\mathrm{R}=-0.8663$

R-squared $=75.05 \%$

R-squared (adjusted for d.f.) $=73.73 \%$

Standard error of estimation - SSE $=0.352$

Mean absolute error - MAE $=0.274$

Durbin-Watson statistics $=1.15<1,4-$ possible autocorrelation of residuals

Table 7. Parameter estimates of multiplicative regression model (WTS)

\begin{tabular}{|c|c|c|c|c|}
\hline Parameter & Estimate & Standard Error & T-stat & P-value \\
\hline Intercept & 12.2007 & 1.9498 & 6.2575 & 0.0000 \\
\hline Slope & -2.3086 & 0.30540 & -7.5593 & 0.0000 \\
\hline
\end{tabular}

* Intercept $=\ln (\mathrm{a})$

Table 8. Analysis of variance table for WTS regression model

\begin{tabular}{|c|c|c|c|c|c|}
\hline Source & DF (Degree of Freedom) & SS (Sum of Squares) & MS (Mean Square) & F-stat & P-value \\
\hline Model & 1 & 7.0957 & 7.0957 & 57.14 & 0.0000 \\
\hline Residual & 19 & 2.3593 & 0.1242 & & \\
\hline Total & 20 & 9.4550 & & & \\
\hline
\end{tabular}

In the next step of the analysis, the confidence limits (internal lines) and prediction limits (outside lines) for the PRD and WTS were determined, assuming the probability of $95 \%$. These model plots (middle line) are shown in Fig. 1 (PRD) and in Fig. 2 (WTS), whereas their fitting to the data are given in Fig. 3 and in Fig. 4 respectively. 


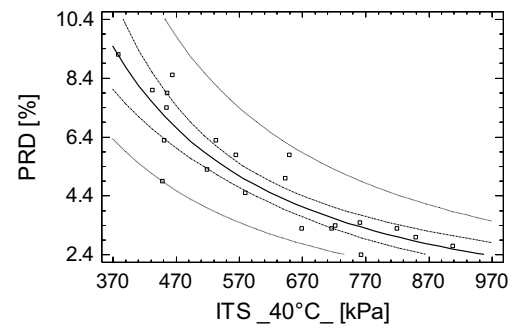

Fig. 1. Dependence between PRD and ITS results for AC samples

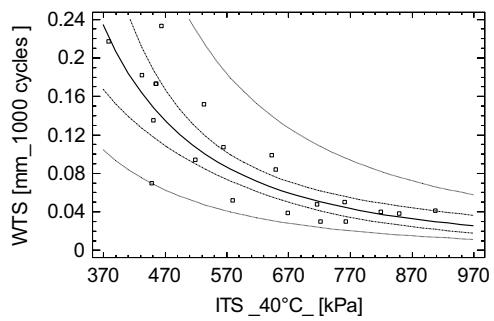

Fig. 2. Dependence between WTS and ITS results for AC samples

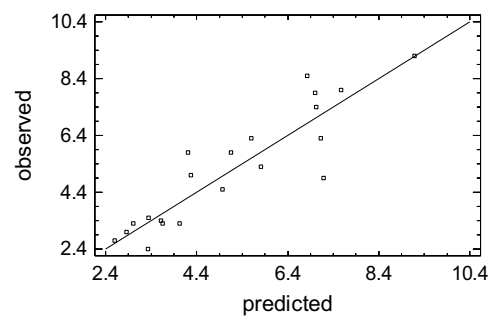

Fig. 3. Relations between observed and predicted PRD value

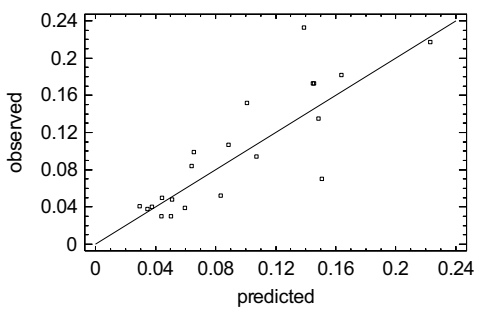

Fig. 4. Relations between observed and predicted WTS value 
On the basis of determined functional models, the predicted values of rutting parameters in a certain range were calculated (PRD: $5-10 \%)$ and WTS $(0.10-0.30 \mathrm{~mm} / 1000$ cycles) along with the determination of prediction limits and confidence limits, with $95 \%$ probability. The results are summarized in Table 9 (PRD) and in Table 10 (WTS). Then, the criterion of the ITS values were adopted at $40^{\circ} \mathrm{C}$ as corresponding to the upper prediction limits for the rutting parameters required by Polish Technical Requirements for Asphalt Mixtures, WT-2 [12] (Table 11). No requirements were given for the wearing coarse, as only one such mixture was tested.

Table 9. Predicted values of ITS for a given PRD values

\begin{tabular}{|c|c|c|c|c|c|}
\hline PRD [\%] & $\begin{array}{c}\text { Predicted ITS } \\
{[\mathrm{kPa}]}\end{array}$ & \multicolumn{2}{|c|}{$95 \%$ prediction limits } & \multicolumn{2}{c|}{$95 \%$ confidence limits } \\
\cline { 3 - 6 } & 578 & lower & upper & lower & upper \\
\hline 5 & 521 & 457 & 732 & 550 & 608 \\
\hline 6 & 477 & 411 & 661 & 492 & 552 \\
\hline 7 & 442 & 375 & 607 & 445 & 511 \\
\hline 8 & 413 & 346 & 564 & 408 & 479 \\
\hline 9 & 389 & 322 & 529 & 376 & 453 \\
\hline 10 & 302 & 501 & 350 & 432 \\
\hline
\end{tabular}

Table 10. Predicted values of ITS for a given WTS values

\begin{tabular}{|c|c|c|c|c|c|}
\hline \multirow{2}{*}{$\begin{array}{c}\text { WTS } \\
{[\mathrm{mm} / 1000 \text { cycles }]}\end{array}$} & $\begin{array}{c}\text { Predicted ITS } \\
{[\mathrm{kPa}]}\end{array}$ & \multicolumn{2}{|c|}{$95 \%$ prediction limits } & \multicolumn{2}{c|}{$95 \%$ confidence limits } \\
\cline { 3 - 6 } & 548 & lower & upper & lower & upper \\
\hline 0.10 & 413 & 728 & 514 & 584 \\
\hline 0.15 & 480 & 360 & 641 & 442 & 522 \\
\hline 0.20 & 438 & 326 & 588 & 395 & 485 \\
\hline 0.25 & 407 & 301 & 550 & 361 & 458 \\
\hline 0.30 & 384 & 282 & 521 & 336 & 438 \\
\hline
\end{tabular}

Table 11. Proposal of AC rutting requirements based on ITS at $40^{\circ} \mathrm{C}(95 \%$ prediction limits)

\begin{tabular}{|c|c|c|c|c|c|c|c|c|}
\hline \multirow{2}{*}{$\begin{array}{c}\text { Asphalt } \\
\text { layer }\end{array}$} & \multicolumn{4}{|c|}{ Traffic category (KR 3-4) } & \multicolumn{4}{c|}{ Traffic category (KR 5-7) } \\
\cline { 2 - 9 } & PRD & WTS & ITS (PRD) & ITS (WTS) & PRD & WTS & ITS (PRD) & ITS (WTS) \\
\hline base & 9 & 0.30 & $\mathbf{5 2 9}$ & 521 & 7 & 0.15 & 607 & $\mathbf{6 4 1}$ \\
\hline binder & 7 & 0.15 & 607 & $\mathbf{6 4 1}$ & 5 & 0.10 & $\mathbf{7 3 2}$ & 728 \\
\hline
\end{tabular}

\section{CONCLUSiOnS}

For both rutting parameters (PRD and WTS), a significant linear correlation with indirect tensile strength, determined at $40^{\circ} \mathrm{C}$ with using a typical Marshall press, was found.

Obtained linear correlation coefficients are negative, i.e. the higher indirect tensile strength the lower values of parameters specifying $\mathrm{AC}$ resistance to rutting. 
It was noticed that the indirect tensile strength tested at $40^{\circ} \mathrm{C}$ is a better estimator of the PRD parameter than the WTS parameter, the resulting functional relations explain here: $82 \%$ of the variability for the PRD parameter and $75 \%$ of the variability for the WTS parameter.

The above analyses confirm earlier American studies [3] that the proposed test, i.e. ITS at $40^{\circ} \mathrm{C}$ at the piston rate of $50 \mathrm{~mm} /$ minute, conducted on samples compacted in a gyratory press, seems to be a good estimation of the resistance of asphalt concrete mix to the permanent deformation damages.

As a continuation of the ITS study, the use of other mixture types as well as samples compacted with a Marshall hammer should be considered, which will popularize the use of this test method.

\section{REFERENCES}

1. G. G. Al-Khateeb, T. I. Al-Suleiman Obaidat, T. S. Khedaywi, M. S. Elayan, "Studying rutting performance of Superpave asphalt mixtures using dynamic crrep and simple performance tests", Road Materials and Pavement Design 19: pp. 315-333, 2018.

2. D. W. Christensen, R. Bonaquist, D. A. Anderson, S. Gokhale, "Indirect tension strength as a simple performance test”, Transportation Research Circular, number E-C068, pp. 44 - 57, Washington, 2004.

3. D. W. Christensen, R. Bonaquist "Using the Indirect Tension Test to Evaluate Rut Resistance in Developing Hot-Mix Asphalt Designs”, Transportation Research Circular, number E-C124, pp. 62 - 77, Washington, 2007.

4. I. Isailovic, M. P. Wistuba, C. F. Augusto, "Permanent deformation of hot mix asphalt under compression and tension", Proceedings of the $6^{\text {th }}$ Euroasphalt \& Eurobitume Congress, No. of pages 13, Prague, 2016.

5. N. P. Khousla, K. I. Harikrishnan, "Tensile Strength - a Design Tool for Superpave Mixtures", No. of pages 188, Department of Civil Engineering, North Carolina State University, Raleight, NC, USA, 2007.

6. J. Kruger, E. Horak, "The appropriateness of accelerated pavement testing to access the rut prediction capability of laboratory asphalt tests", Proceedings of the $24^{\text {th }}$ Southern African Transport Conference, pp. 380-390, Pretoria, 2005.

7. V. Radhakrishnnan, R. R. Dudipal, A. Maity, K. S. Reddy, "Evaluation of rutting potential of asphalt using resilient modulus test parameters", Road Materials and Pavement Design 20: pp. 20-35, 2019.

8. T. Xu, H. Wang, Z. Li, Y. Zhao, "Evaluation of permanent deformation of asphalt mixtures using different laboratory performance tests", Construction and Building Materials 53: pp. 561-567, 2014.

9. J. P. Zaniewski, G. Srinivasan, "Evaluation of Indirect Tensile Strength to Identity Asphalt Concrete Rutting Potential", No. of pages 73, Department of Civil and Environmental Engineering, West Virginia University, Morgantown, USA, 2004.

10. J. Zhang, A. E Alvarez, S. I. Lee, A. Torres, L. F Walubita, "Comparison of flow number, dynamic modulus, and repeated load tests for evaluation of HMA permanent deformation", Construction and Building Materials 44: pp. 391-398, 2013.

11. Computer Program Statgraphics Plus v. 5.1, A Manugistics Inc. Product, Rockville, MD USA, 2000,

12. Nawierzchnie asfaltowe na drogach krajowych, WT-2, mieszanki mineralno-asfaltowe, Wymagania techniczne, GDDKiA, Warszawa, 2014.

13. PN-EN 12697-22 Bituminous Mixtures. Test methods for hot mix asphalt. Whell tracking.

14. PN-EN 12697-23 Bituminous Mixtures. Test methods for hot mix asphalt. Determination of the indirect tensile strength of bituminous specimens.

15. PN-EN 12697-30 Bituminous Mixtures. Test methods for hot mix asphalt. Specimen preparation by impact compactor.

16. PN-EN 12697-31 Bituminous Mixtures. Test methods for hot mix asphalt. Specimen preparation by gyratory compactor.

17. PN-EN 12697-33 Bituminous Mixtures. Test methods for hot mix asphalt. Specimen preparation by roller compactor. 


\section{LIST OF FIGURES AND TABLES:}

Fig. 1. Dependence between PRD and ITS results for AC samples

Rys. 1. Zależność pomiędzy wartościami PRD i ITS dla próbek betonu asfaltowego

Fig. 2. Dependence between WTS and ITS results for AC samples

Rys. 2. Zależność pomiędzy wartościami WTS i ITS dla próbek betonu asfaltowego

Tab. 1. Composition and physical characteristics of AC samples compacted in a gyratory press

Tab. 1. Skład i cechy fizyczne próbek betonu asfaltowego zagęszczanych w prasie żyratorowej

Tab. 2. Results of rutting and ITS for AC samples

Tab. 2. Wyniki badań parametrów koleinowania i ITS dla próbek betonu asfaltowego

Tab. 3. Results of correlation coefficients and their statistical significance tests (P-value)

Tab. 3. Współczynniki korelacji wraz z ich analizą istotności statystycznej (wartość prawdopodobieństwa)

Tab. 4. Comparison of alternative regression models

Tab. 4. Porównanie alternatywnych modeli regresji

Tab. 5. Parameter estimates of multiplicative regression model (PRD)

Tab. 5. Oszacowanie parametrów modelu iloczynowego dla PRD

Tab. 6. Analysis of variance table for PRD regression model

Tab. 6. Tablica analizy wariancji modelu regresji dla PRD

Tab. 7. Parameter estimates of multiplicative regression model (WTS)

Tab. 7. Oszacowanie parametrów modelu iloczynowego dla WTS

Tab. 8. Analysis of variance table for WTS regression model

Tab. 8. Tablica analizy wariancji modelu regresji dla WTS

Tab. 9. Predicted values of ITS for a given PRD values

Tab. 9. Prognozowane wartości ITS dla danych wartości PRD

Tab. 10. Predicted values of ITS for a given WTS values

Tab. 10. Prognozowane wartości ITS dla danych wartości WTS

Tab. 11. Proposal of AC rutting requirements based on ITS at $40^{\circ} \mathrm{C}(95 \%$ prediction limits)

Tab. 11. Propozycja wymagań odporności na koleinowanie dla betonów asfaltowych na podstawie badania ITS w $40^{\circ} \mathrm{C}$ (granice prognozowania dla 95\%) 


\title{
BADANIE WYTRZYMALOŚCI NA ROZCIĄGANIE POŚREDNIE JAKO PROSTA METODA OCENY ODPORNOŚCI NA KOLEINOWANIE DLA BETONU ASFALTOWEGO
}

\author{
Slowa kluczowe: beton asfaltowy (AC), wytrzymałość na rozciąganie pośrednie (ITS), proporcjonalna głębokość koleiny \\ (PRD), szybkość przyrostu koleiny (WTS), deformacje trwałe nawierzchni asfaltowej
}

\section{STRESZCZENIE:}

Odporność mieszanek mineralno-asfaltowych (MMA) na powstawanie deformacji trwałych jest jednym z podstawowych wymagań, które należy zapewnić podczas projektowania składu mieszanki. Najczęściej stosuje się do tego celu badania koleinowania na laboratoryjnie zagęszczanych próbkach MMA, co wymaga stosunkowo dużych próbek oraz użycia specjalistycznej aparatury, zarówno do zagęszczenia takich próbek jak i samego ich badania. W związku z powyższym, w wielu krajach prowadzone są badania celem wytypowania prostego testu, który można wykonać z wykorzystaniem powszechnie dostępnych w laboratoriach drogowych urządzeń (np. prasa Marshalla), na standardowo przygotowywanych próbkach MMA. Zgodnie z wynikami prac prowadzonych przez Christensena i Bonaquista, Zaniewskiego i Srinivasana jak również Khousla i Harikrishnanna takim badaniem może być wytrzymałość na rozciąganie pośrednie (ITS), przy odpowiednim dostosowaniu temperatury badania jak również szybkości przesuwu tłoka w prasie. Dla celów praktycznych rekomendowane jest użycie standardowej prasy Marshalla o prędkości przesuwu tłoka $50 \mathrm{~mm} /$ minutę, przy temperaturze badania równej $40^{\circ} \mathrm{C}$. W niniejszej publikacji przedstawiono badania zależności pomiędzy wynikami ITS, przeprowadzonego wg wyżej wymienionych warunków, oraz parametrami koleinowania w małym koleinomierzu w

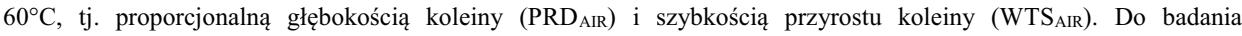
wytrzymałości na rozciąganie pośrednie przeznaczono próbki o średnicy $100 \mathrm{~mm}$ zagęszczone w prasie żyratorowej, natomiast do badania koleinowania przygotowano płyty o wymiarach 305 x $305 \mathrm{~mm}$ i wysokości $40 \mathrm{~mm}$ lub $60 \mathrm{~mm}$, zależnie od uziarnienia badanej MMA. Przebadano łącznie 21 mieszanek betonu asfaltowego przeznaczonego do warstw podbudowy, wiążącej i ścieralnej o uziarnieniach $0 / 22 \mathrm{~mm}, 0 / 16 \mathrm{~mm}$ i 0/8 mm. W mieszankach tych stosowano różne asfalty tj.: drogowe niemodyfikowane (35/50 i 50/70), modyfikowane polimerami (PMB 25/55-60, PMB 45/80-55), modyfikowane gumą (wg rozwiązań patentowych). Dodatkowo w niektórych mieszankach stosowano dodatek granulatu asfaltowego (RAP) lub granulatu papy (RAS). Uzyskane wartości średnie dla poszczególnych MMA, dotyczące: ITS, parametrów koleinowania (PRD i WTS), parametrów składu MMA takich jak zawartość lepiszcza, wolne przestrzenie w MMA, wolne przestrzenie w mieszance mineralnej (VMA) oraz wypełnienie wolnych przestrzeni w mieszance mineralnej przez asfalt (VFB), zostały poddane analizom korelacji liniowej. Uzyskane korelacje z parametrami koleinowania okazały się istotne tylko w przypadku wyników ITS, współczynniki korelacji są ujemne i wynoszą odpowiednio: - 0.82 dla parametru WTS oraz -0.88 dla parametru PRD. Właściwości opisujące skład betonu asfaltowego uzyskały względem parametrów koleinowania nieistotne współczynniki korelacji, w granicach $0.04-0.30$. W analizie regresji porównano funkcje opisujące zależność pomiędzy ITS i parametrami koleinowania, najlepsze dopasowania w obu przypadkach uzyskał model iloczynowy, co jest zgodne z wynikami prac Christensena i Bonaquista. Analiza wariancji przy przyjętym poziomie ufności (95\%) wykazała, że uzyskane modele są statystycznie istotne, skorygowane współczynniki determinacji wyniosły: 82\% dla parametru PRD i 74\% dla parametru WTS. Opierając się na uzyskanych zależnościach funkcyjnych wyznaczono granice ufności i granice oszacowania dla przyjętych przedziałów wartości PRD $(5-10 \%)$ i WTS $(0.10-0.30 \mathrm{~mm} / 1000$ cykli). Następnie odnosząc się do wymaganych poziomów parametrów koleinowania podanych w Wymaganiach Technicznych WT-2 2014, dla konkretnej lokalizacji warstwy asfaltowej w 
nawierzchni (podbudowa, warstwa wiążąca) oraz zakresu kategorii ruchu (KR3-4 lub KR5-7), wyznaczono kryteria dla wytrzymałości na rozciąganie pośrednie w odniesieniu do obu parametrów koleinowania tj. PRD i WTS. Zaproponowane kryteria wyliczono jako górną granicę przedziału oszacowania z prawdopodobieństwem 95\%, co jest rozwiązaniem bardziej bezpiecznym niż przyjęcie jako kryterium górnej granicy przedziału ufności. W przedstawionych analizach pominięto wyznaczenie kryteriów dla warstwy ścieralnej, ponieważ badaniami objęto tylko jedną taką mieszankę. Jako kontynuację badań ITS należy rozważyć rozszerzenie badań także na inne mieszanki, zwłaszcza przeznaczone do warstwy ścieralnej, oraz użycie próbek MMA zagęszczonych za pomocą ubijaka Marshalla, co upowszechni zastosowanie przedmiotowej metody badawczej.

Received 13.04.2019

Revised 27.08.2019 
